\title{
Penerapan blended learning dengan pendekatan STEM untuk meningkatkan kemampuan literasi sains siswa pada pembelajaran biologi di masa pandemi covid-19
}

\author{
Lidya Banilaa,1, Hana Lestarib,1, ${ }^{*}$ Ridwan Siskandar ${ }^{c, 3}$ \\ a SMAN 1 Bojong Gede, Bogor, Indonesia \\ ${ }^{\mathrm{b}}$ Institut Agama Islam Sahid Bogor, Bogor, Indonesia \\ ${ }^{c}$ Sekolah Vokasi Institut Pertanian Bogor, Indonesia \\ 2 hanalestari3011@gmail.com* \\ * Corresponding Author
}

Received 5 Maret 2021; accepted 17 Maret 2021; published 20 Maret 2021

\begin{abstract}
ABSTRAK
Penelitian ini bertujuan untuk memperoleh informasi tentang bagaimana penerapan model blended learning dengan pendekatan STEM terhadap keterampilan literasi sains siswa pada konsep cendawan pada saat pandemi COVID. Metode penelitian yang digunakan adalah pre-eksperimen dengan one group pretest-posttest design. Penelitian ini dilaksanakan di SMAN 1 Bojong Gede Kabupaten Bogor pada tahun ajaran 2020/2021. Sampel menggunakan dua kelas $X$ yang dipilih secara purposive sampling. Instrumen penelitian ini adalah tes literasi sains siswa yang berisi 20 butir soal. Teknik pengolahan data dilakukan secara deskriptif, kemudian data dianalisis secara inferensial dengan tes wilcoxon. Hasil penelitian menunjukkan bahwa secara umum rata-rata kemampuan literasi sains siswa dari penerapan model blended learning dengan pendekatan STEM memiliki skor rata-rata 85,50 dengan kategori baik. Agar siswa memiliki pemahaman literasi sains yang lebih baik, pemahaman siswa terhadap sains harus terus dilatih melalui model blended learning dengan pendekatan STEM.
\end{abstract}

\section{Application of Blended Learning with a STEM Approach to Improve Students' Science Literacy Ability during the Covid 19 Pandemic}

This study aims to obtain information about how to apply the blended learning model with the STEM approach to students' scientific literacy skills on the fungal concept during the COVID pandemic. The research method used was preexperiment with one group pretest-posttest design. This research was conducted at SMAN 1 Bojong Gede Bogor Regency in the academic year 2020/2021. The sample used two $X$ classes selected by purposive sampling. The research instrument was a student's scientific literacy test which contained 20 items. The data processing technique was carried out descriptively, then the data were analyzed inferentially with the Wilcoxon test. The results showed that in general the average scientific literacy ability of students from the application of the blended learning model with the STEM approach had an average score of 85.50 in the good category. In order for students to have a better understanding of scientific literacy, students' understanding of science must continue to be trained through a blended learning model with a STEM approach..
KATAKUNCI

Pembelajaran campuran,

keterampilan literasi ilmiah, STEM

\section{KEYWORDS}

Blended

learning,

Scientific

literacy skills, STEM

This is an openaccess article under the $\underline{\text { CC-BY-SA }}$ license

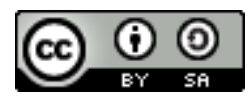

\section{Pendahuluan}

Pembelajaran biologi merupakan pembelajaran yang memberikan pengalaman belajar secara langsung dan bermakna untuk mengembangkan kompetensi siswa agar lebih memahami alam sekitar. Secara garis besar pembelajaran biologi memiliki tiga komponen utama dalam pembelajarannya, yaitu sikap ilmiah, proses ilmiah dan produk 
ilmiah. Dalam kaitannya dengan pembelajaran, hendaknya biologi bukan hanya terpaku pada konsep. Akan tetapi memberikan pengalaman langsung dalam pengembangan penguasaan produk, proses, dan sikap ilmiah atau lebih luasnya menguasai literasi sains (Arlis et al., 2020). Literasi sains merupakan pengetahuan dan pemahaman tentang konsep-konsep ilmiah dan proses yang diperlukan untuk memecahkan permasalahan dan menarik kesimpulan berdasarkan bukti dalam rangka memahami serta mengambil keputusan berkenaan dengan alam dan perubahan yang dilakukan terhadap alam melalui manusia (Becker, 2011). Literasi sains sangat penting untuk mempersiapkan bekal keterampilan yang harus dimiliki siswa di abad ke 21 dari tingkat sekolah dasar sampai perguruan tinggi yang meliputi keterampilan berpikir kritis, kreatif, kolaboratif dan komunikasi.

Berdasarkan hasil evaluasi dari Programme for International Student Assessment (PISA), pada tahun 2015 menempatkan Indonesia pada urutan terbawah yaitu dari 72 negara yang berpartisipasi, Indonesia menempati urutan ke-8 dari bawah. PISA merupakan evaluasi berskala internasional, diselenggarakan di 50 negara untuk mengukur dan membandingkan literasi membaca, matematika dan sains siswa-siswa suatu negara dengan negara peserta lain, sehingga dapat memberikan gambaran mengenai kekuatan dan kelemahan sistem pendidikan masing-masing negara. Data hasil evaluasi PISA menunjukan bahwa kemampuan literasi sains siswa di Indonesia dalam kategori rendah Low Internasional Bencmark (Yuliati, 2017). Rendahnya literasi sains siswa di Indonesia disebabkan oleh beberapa faktor diantaranya: Rendahnya pemahaman siswa terhadap hakikat sains atau Nature of science (NoS) (Lestari \& Widodo, 2021); siswa memahami sains sebatas teori saja siswa belum mampu mengaplikasikan konsep sains dalam kehidupan sehari-hari (Lestari, Banila, \& Siskandar, 2019); Rendahnya kemampuan siswa dalam membaca, menginterpretasikan data dalam bentuk gambar, tabel, diagram dan bentuk penyajian lainnya; Rendahnya kemampuan siswa dalam berpikir tingkat tinggi seperti memecahkan permasalahan, bernalar ilmiah, berpikir kritis dan berpikir kreatif (Sopandi, 2019).

Kemampuan literasi sains siswa dapat dikembangkan dan ditingkatkan dengan metode yang tepat dan didukung oleh teknologi yang memadai (Fitriyana, Wiyarsi, Ikhsan, \& Sugiyarto, 2020; Lestari, Setiawan, \& Siskandar, 2020). Teknologi menjadi penunjang pembelajaran yang sangat penting dalam pembelajaran, apalagi saat ini sedang dalam masa pandemi Covid-19. Sudah hampir 1 tahun, Indonesia dilanda pandemi Covid 19, sehingga mengharuskan masyarakat untuk beribadah, belajar dan bekerja dari rumah. Masyarakat sudah memasuki tatanan kehidupan baru yang disebut New Normal dalam menghadapi pandemi Covid 19. New Normal merupakan kehidupan masyarakat secara normal dengan tetap melakukan berbagai kegiatan namun dengan pola hidup yang menerapkan protokol kesehatan secara ketat untuk mencegah penyebaran dan penularan Covid-19 (Jarwati \& Priskawati, 2020). Protokol kesehatan yang dimaksud yakni, rajin mencuci tangan dengan sabun, menggunakan masker, menjaga jarak dan menerapkan pola hidup bersih dan sehat.

Pada masa new normal, pembelajaran di sekolah menengah atas memasuki pembelajaran normal, sehingga diperlukan penerapan sistem pembelajaran yang dapat memadukan pembelajaran daring maupun luring namun tetap menerapkan protokol kesehatan. Pembelajaran daring merupakan pembelajaran yang dilakukan dengan menggunakan internet sehingga guru dan siswa tidak perlu bertatap muka dalam proses pembelajaran (Setiawan \& Iasha, 2020). Sedangkan pembelajaran luring merupakan 
pembelajaran di luar jaringan yang tidak memanfaatkan akses internet (Fauzi \& Sastra Khusuma, 2020). Salah satu model pembelajaran yang dapat diterapkan di masa bukan pandemic covid-19 misalnya metode pembelajaran inkuiri (Aprilia, Lestariningsih, \& Ayatusa'adah, 2020; Asiyah, Walid, \& Topano, 2020), sedangkan salah satu model pembelajaran yang dapat diterapkan pada pembelajaran new normal dan dapat meningkatkan kemampuan literasi sains siswa yakni blended learning dengan pendekatan STEM.

Blended learning adalah pola pembelajaran campuran antara pembelajaran tatap muka maupun secara daring (Lestari \& Siskandar, 2020). Pembelajaran blended learning di masa new normal ini menggunakan media online dengan memanfaatkan multimedia baik sinkron (synchronous) dan asinkron (asynchronous) (Dhawan, 2020). Pembelajaran synchronous merupakan bentuk pembelajaran dengan interaksi langsung antar siswa dan guru sekaligus menggunakan formulir online seperti konferensi dan obrolan online. Sedangkan asynchronous merupakan salah satu bentuk pembelajaran secara tidak langsung (tidak pada waktu yang bersamaan) dengan menggunakan pendekatan belajar mandiri (Borup, Chambers, \& Srimson, 2019; Richardson, Lingat, Hollis, College, \& Pritchard, 2020).

Blended learning memiliki karakteristik ruang belajar yakni, sinkron secara langsung, sinkron secara virtual, asinkron kolaboratif dan asinkron mandiri. Sinkron secara langsung menerapkan pembelajaran dengan tatap muka secara langsung dalam waktu yang sama; sinkron secara virtual menerapkan pembelajaran secara langsung namun dilakukan dengan tatap maya dalam waktu yang sama tetapi tempat yang berbeda; asinkron kolaboratif merupakan pembelajaran dengan menerapkan pembelajaran secara bersama dengan orang lain dimanapun dan kapanpun dengan menggunakan media diskusi seperti blog, chating room, whatsapp group; sedangkan asinkron mandiri menerapkan pemberlajaran secara mandiri dimanapun dan kapanpun dengan menggunakan media video, TV, radio maupun podcast (Chaeruman \& Maudiarti, 2018). Adapun pada masa pandemi ini, dari keempat ruang belajar, hanya sinkron secara langsung yang tidak bisa diimplementasikan.

Pembelajaran blended learning memiliki tiga tahapan yakni (1) Seeking of information, pencarian informasi dari berbagai sumber informasi yang tersedia secara asynchronous mandiri berdasarkan pada relevansi, validitas, reliabilitas konten dan kejelasan akademis; (2) Acquisition of information menemukan, memahami, serta mengkonfrontasikannya dengan ide atau gagasan yang telah ada dalam pikiran kemudian menginterprestasikan informasi/pengetahuan dari berbagai sumber yang tersedia, sampai mereka mampu mengkomunikasikan kembali dan menginterpretasikan ide-ide dan hasil interprestasinya secara asynchronous kolaboratif; (3) Synthesizing of knowledge , mengkonstruksi/merekonstruksi pengetahuan melalui proses asimilasi dan akomodasi bertolak dari hasil analisis, diskusi dan perumusan kesimpulan dari informasi yang diperoleh. Kembali dan menginterpretasikan ide-ide dan hasil interprestasinya secara synchronous virtual dan asynchronous mandiri (Chaeruman \& Maudiarti, 2018; Lestari \& Siskandar, 2020).

Pembelajaran dengan pendekatan STEM (Science, Technology, Engineering and Mathematics) merupakan pembelajaran yang mengintegrasikan keempat komponen yakni sains, teknologi, teknik dan matematika dalam satu pengalaman belajar membantu siswa memanfaatkan teknologi dan merangkai menjadi percobaan yang dapat membuktikan konsep sains yang didukung oleh data yang telah dikelola secara matematis 
(Lestari \& Rahmawati, 2020). Pendekatan STEM dapat membuat pembelajaran menjadi inovatif dan variatif berkaitan dengan kehidupan sehari-hari. Siswa dapat memahami lingkungan hidup dan masalah yang dihadapi oleh masyarakat modern yang sangat bergantung pada perkembangan ilmu pengetahuan dan teknologi, termasuk juga masalah sosial kemasyarakatan (Daugherty, 2013). Pendekatan STEM dapat membimbing dan melatih siswa untuk berpikir logis, kritis, evaluatif, kreatif dalam memecahkan masalah dan mengambil sebuah keputusan berkaitan dalam menangani masalah kehidupan dengan memanfaatkan teknologi dan mengaplikasikannya dalam kehidupan nyata (Ceylan \& Ozdilek, 2015).

Blended learning dengan pendekatan STEM yang diterapkan pada penelitian ini yakni pembelajaran yang menekankan pendekatan STEM namun dilakukan secara blended learning baik secara sinkron (synchronous) dan asinkron (asynchronous) dengan memanfaatkan berbagai teknologi yang ada seperti e-learning, LMS, video, podcast, maupun Televisi. Oleh karena itu, berdasarkan latar belakang yang sudah dipaparkan, penelitian ini bertujuan untuk mengetahui penerapan model blended learning dengan pendekatan STEM untuk meningkatkan literasi sains siswa pada pokok bahasan fungi selama masa pandemi Covid-19.

\section{Metode}

Metode penelitian yang digunakan adalah pre-ekperimen dengan desain one grup pretest posttest (Creswell, 2014). Perlakuan dalam penelitian ini yaitu penerapan blended learning dengan pendekatan STEM. Adapun desain penelitian one grup pretest posttest pada tabel berikut.

Tabel 1. Desain Penelitian one group pretest postest.

\begin{tabular}{lll}
\hline $\mathrm{O}_{1}$ & $\mathrm{X}$ & $\mathrm{O}_{2}$ \\
\hline
\end{tabular}

Keterangan:

$\mathrm{O}_{1} \quad$ : Tes kemampuan literasi sains siswa sebelum pembelajaran

$\mathrm{O}_{2} \quad$ : Tes kemampuan literasi sains siswa setelah pembelajaran

$\mathrm{X} \quad$ : Penerapan blended learning dengan pendekatan STEM

Subjek penelitian yang dilibatkan adalah siswa kelas X IPA 1 dan X IPA 2 di SMAN 1 Bojong Gede sebanyak 56 siswa pada tahun ajaran 2020-2021 ganjil yang telah dipilih sebagai secara purposive sampling. Instrumen penelitian yang digunakan adalah soal literasi sains dengan bentuk tes pilihan ganda pada pokok bahasan fungi. Literasi sains di kembangkan berdasarkan indikator mengindentifikasi isu ilmiah, menjelaskan fenomena ilmiah, dan menggunakan bukti ilmiah (Lestari \& Siskandar, 2020). Adapun kisi-kisi literasi sains siswa disajikan pada Tabel 2

Tabel 2. Kemampuan Kisi-Kisi Literasi Sains Siswa

\begin{tabular}{lcl}
\hline No & $\begin{array}{c}\text { Kompetensi Ilmiah yang Diukur } \\
\text { dalam Literasi Sains }\end{array}$ & \multicolumn{1}{c}{ Indikator } \\
\hline 1. & Mengidentifikasi isu-isu (masalah) ilmiah & $\begin{array}{l}\text { Mengidentifikasi pendapat ilmiah yang valid (misalnya } \\
\text { pendapat/teori untuk mendukung hipotesis) } \\
\text { Melakukan penelusuran literatur yang efektif (misalnya } \\
\text { mengevaluasi validitas sumber dan membedakan diantara tipe }\end{array}$ \\
2. & Menjelaskan fenomena ilmiah & $\begin{array}{l}\text { Membuat grafik secara tepat dari data } \\
\text { Memecahkan masalah menggunakan keterampilan kuantitatif, } \\
\end{array}$ \\
& $\begin{array}{l}\text { termasuk statistik dasar (misalnya menghitung rata-rata, } \\
\text { probabilitas, persentase, frekuensi) }\end{array}$
\end{tabular}




\begin{tabular}{|c|c|c|}
\hline No & $\begin{array}{c}\text { Kompetensi Ilmiah yang Diukur } \\
\text { dalam Literasi Sains }\end{array}$ & Indikator \\
\hline & & 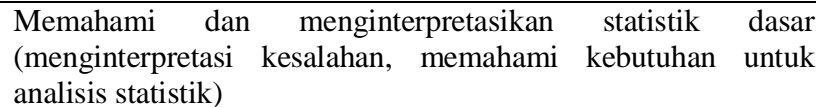 \\
\hline 3. & Menggunakan bukti ilmiah & $\begin{array}{l}\text { Melakukan inferensi, prediksi, dan penarikan kesimpulan } \\
\text { berdasarkan data kuantitatif }\end{array}$ \\
\hline
\end{tabular}

Teknik pengolahan data dilakukan secara deskriptif dengan menghitung rata-rata dan persentase setiap item untuk memperoleh gambaran kemampuan literasi sains siswa, kemudian data di analisis secara inferensial dengan uji t paired sample menggunakan sofware SPSS versi 22, untuk melihat perbedaan literasi sains sebelum dan sesudah pembelajaran blended learning dengan pendekatan STEM.

\section{Hasil dan Pembahasan}

Data di analisis secara statistik deskriptif, dan didapatkan data rata-rata kemampuan literasi sains siswa, sebelum dengan sesudah pembelajaran blended learning dengan pendekatan STEM dilihat pada Tabel 3 berikut ini.

Tabel 3. Kemampuan Literasi Sains Siswa Pada Setiap Indikator

\begin{tabular}{clcc}
\hline No & \multicolumn{1}{c}{ Indikator Literasi Sains } & Post test & Pre test \\
\hline 1 & Mengidentifikasi pendapat ilmiah & 85 & 70 \\
2 & Melakukan penelusuran literatur yang efektif & 87 & 74 \\
3 & Membuat grafik secara tepat dari data & 86 & 72 \\
4 & Memecahkan masalah & 86 & 71 \\
5 & Memahami dan menginterpretasikan statistik dasar & 84 & 70 \\
6 & Melakukan inferensi, prediksi, dan penarikan & & 75 \\
\hline 7 & kesimpulan & 85 & 72.00 \\
\hline
\end{tabular}

Tabel 3 menunjukkan bahwa terdapat peningkatan kemampuan literasi sains siswa sebelum dengan setelah pembelajaran blended learning dengan pendekatan STEM. Rata-rata literasi sains sebelumnya adalah 72,00, menjadi 85,50. Dapat disimpulkan bahwa terdapat perbedaan kemampuan literasi sains siswa sebelum dan setelah pembelajaran blended learning dengan pendekatan STEM. Untuk menentukan apakah terdapat perbedaan yang signifikan literasi sains sebelum dan setelah pemberian pembelajaran blended learning dengan pendekatan STEM, maka data di uji dengan paired sample $t$ test menggunakan software SPSS 22 pada $\alpha$ (0.05), dan didapatkan output sebagai berikut:

Tabel 4. Hasil Uji Wilcoxon

\begin{tabular}{l|c|c|c|c|c|c}
\hline & $\boldsymbol{N}$ & Mean & Median & Modus & $\begin{array}{c}\text { Standar } \\
\text { Deviasi }\end{array}$ & \multirow{2}{*}{ Sig (2-Tailed) } \\
\cline { 2 - 5 } Pre Test & 52 & 72.00 & 72.00 & 72.00 & 0.15 & 0.000 \\
Post Test & 52 & 85.50 & 85.00 & 85.00 & 0.08 & \\
\hline
\end{tabular}

Di dapatkan nilai probabilitas (sig) sebesar o,ooo lebih kecil $\alpha$ (0.05), maka Ho di tolak dan $\mathrm{H}_{1}$ diterima artinya hasil penelitian menunjukkan bahwa terdapat perbedaan yang signifikan pada kemampuan literasi sains siswa di pretest dan post-test. Nilai ratarata tes menunjukkan bahwa nilai post-test lebih tinggi daripada sebelumnya. Oleh karena itu, temuan tersebut menunjukkan bahwa kemampuan literasi sains siswa, setelah intervensi pembelajaran blended learning dengan pendekatan STEM mengalami peningkatan. 
Hasil analisis data menunjukkan bahwa kemampuan literasi sains siswa setelah proses pembelajaran mengalami peningkatan yang signifikan, dikarenakan setiap indikator kemampuan literasi sains siswa dikembangkan melalui pembelajaran blended learning dengan pendekatan STEM. Pembelajaran blended learning diterapkan secara synchronous virtual yakni pembelajaran secara langsung dilakukan dengan tatap maya dalam waktu yang sama tetapi tempat yang berbeda melalui media zoom meeting serta secara asynchronous mandiri maupun kolaboratif dengan bentuk pembelajaran secara tidak langsung (tidak pada waktu yang bersamaan) baik asynchronous kolaboratif media diskusi dengan blog, chating room, whatsapp group dan asynchronous mandiri dengan menggunakan media video, TV, radio maupun podcast (Chaeruman \& Maudiarti, 2018).

Blended learning dengan pendekatan STEM memiliki tiga tahapan yaitu tahapan pertama yakni Seeking of information; pada tahap ini siswa mengembangkan pengetahuan sains siswa dari aspek social, budaya atau tata nilai masyarakat melalui kegiatan asynchronous mandiri dimana siswa mempelajari dan mencari referensi dari berbagai sumber yang terkait dengan topik sains yang sedang up to date di masyarakat melalui video, TV, radio maupun podcast yang telah diarahkan dan ditentukan oleh guru. Aspek pendekatan STEM yang dilatih yakni aspek sains dan teknologi. Adapun kemampuan literasi sains yang dilatih pada tahap ini adalah kemampuan melalukan penelusuran literatur yang efektif dengan presentase $87 \%$ artinya siswa sudah baik dalam membaca dan menelusuri literatur terkait dengan topik yang dipelajari dan indikator mengidentifikasi pendapat ilmiah dengan presentase 85\% artinya siswa sudah cukup baik dalam memahami pendapat ilmiah yang membangun materi yang dipelajari.

Tahap kedua yakni Acquisition of information; pada tahap ini siswa mengembangkan sikap empiris dengan melakukan pengamatan, diskusi dengan etos kerja dan kreativitas melalui kegiatan secara asynchronous kolaboratif yaitu melakukan pengamatan mengenai topik yang sedang dipelajari (topik diberikan oleh guru untuk masing-masing kelompok), siswa merumuskan masalah mengajukan hipotesis, dan menuliskan cara kerja, mencatat data hasil pengamatan, menyimpulkan hasil pengamatan secara asynchronous kolaboratif dengan merekam kegiatan tersebut kemudian mengunggahnya di blog dan hasil diskusi kelompok di kirim ke blog guru dan siswa diberi kesempatan untuk menanggapai hasil diskusi melalui kolom komentar guru. Aspek pendekatan STEM yang dilatih yakni sains, teknologi, teknik dan matematik. Pada tahap ini kemampuan literasi sains yang dilatih adalah memahami dan menginterpretasikan statistik dasar, membuat grafik secara tepat dari data, memecahkan masalah. Untuk indikator literasi sains memahami dan menginterpretasikan statistik dasar dengan presentase $84 \%$ artinya kemampuan siswa dalam kategori baik menginterpretasikan statistik dasar dari hasil pengamatan. Indikator membuat grafik secara tepat dari data dengan presentase $86 \%$ artinya siswa sudah baik dalam membuat grafik dari hasil pengamatan yang diperoleh saat kegiatan observasi dan diskusi. Indikator memecahkan masalah dengan presentase $86 \%$ artinya siswa sudah baik dalam memecahkan permasalahan dari hasil diskusi, pengamatan dan observasi yang dilakukan.

Tahap ketiga yakni Synthesizing Knowledge; pada tahap ini siswa bekerjasama dan berkolaborasi untuk mempresentasikan hasil diskusi kelompok dan guru bersamasama menyimpulkan materi yang dipelajari pada pembelajaran ini pada kegiatan synchronous virtual melalui zoom meeting serta secara asynchronous mandiri dengan siswa mengunggah hasil akhir diskusi presentasi dan simpulan hasil pembelajaran laman LMS secara online. Pada tahap ini kemampuan literasi sains siswa yang dilatih adalah 
melakukan inferensi, prediksi dan penarikan kesimpulan dan mendapat presentase sebesar $85 \%$ yang artinya siswa sudah baik dalam menarik kesimpulan hasil dari diskusi dan pengamatan.

Berdasarkan hasil penelitian, ketiga tahapan blended learning tersebut sudah berorientasi kepada pendekatan STEM, memfasilitasi semua aspek sains (siswa dituntut untuk mampu menggunakan ilmu pengetahuan alam yang diperolehnya dalam menyelesaikan suatu masalah dikehidupannya sehari-hari), teknologi (siswa dituntut untuk mampu berkolaborasi dalam penggunaan teknologi untuk menyampaikan informasi maupun untuk mengolah data yang ditemukan), teknik (siswa mengkolaborasikan hasil temuannya untuk mencari solusi-solusi yang tepat atau bahkan menciptakan suatu produk) maupun matematika (siswa dapat menggunakan ilmu matematika yang dimilikinya ketika mereka mengolah data) dengan memanfaatkan teknologi yang ada baik secara synchronous maupun asynchronous (Han, Rosli, Capraro, \& Capraro, 2016)

Blended learning dengan pendekatan STEM, menawarkan potensi untuk meningkatkan proses belajar mengajar dalam lingkungan pendidikan yang responsif terhadap gaya hidup siswa kontemporer (Dziuban, Graham, Moskal, Norberg, \& Sicilia, 2018). Inovasi teknologi memperluas jangkauan solusi pembelajaran, menciptakan pengalaman belajar yang lebih efektif, meningkatkan akses dan fleksibilitas atau mengurangi biaya belajar, hal ini sangat sesuai dengan kondisi pembelajaran pada masa new normal yang membutuhkan inovasi dan kreatifitas dalam rangka mengelola pembelajaran, pembelajaran yang dapat diakses dengan mudah dan bersifat fleksibel (Bryan, Volchenkova, 2016). Dengan dilaksanakanya pembelajaran synchronous maupun asynchronous berorietasi pendekatan STEM tentunya memanfaatkan teknologi informasi yang tentunya akan merubah arah pedagodi menjadi pedagodi digital. Pedagodi digital mempengaruhi gaya dan startegi mengajar guru dalam memanfaatkan keempat aspek pada pendekatan STEM yakni aspek sains, teknologi, teknik dan matematika. Penelitian yang dilakukan oleh Budiharti (2015) menyatakan bahwa pembelajaran blended learning mampu meningkatkan penguasaan konsep dan penalaran siswa. Sedangkan pendekatan STEM mengacu pada prinsip dan ide yang memberikan deskripsi sains yang valid sebagai cara untuk mengetahui serta karakteristik pengembangan pengetahuan ilmiah mengandung empat hal, yaitu: konten atau produk, proses atau metode, sikap dan teknologi (Lestari \& Rahmawati, 2020). Pendekatan STEM merupakan pendekatan dalam pembelajaran untuk memperoleh pengetahuan, atau nilai-nilai dan keyakinan-keyakinan yang melekat pada pengetahuan ilmiah dan pengembangan kemampuan literasi sains siswa melalui kegiatan-kegiatan mengobservasi, merumuskan pertanyaan yang relevan, mengevaluasi buku dan sumber-sumber informasi lain secara kritis, merencanakan penyelidikan atau investigasi, mereview apa yang telah diketahui, melaksanakan percobaan atau eksperimen dengan menggunakan alat untuk memperoleh data, menganalisis dan menginterpretasi data, serta membuat prediksi dan mengkomunikasikan hasilnya dengan bantuan alat dan teknologi digital seperti blog, website maupun media sosial saat ini dengan menggabungkan pembelajaran online secara synchronous maupun asynchronous (Soler, Soler, \& Araya, 2017).

\section{Kesimpulan}

Hasil dari penelitian ini didapatkan kesimpulan bahwa pengusaan konsep siswa sebelum menggunakan model siklus belajar tipe empiris induktif pada konsep transporasi 
tumbuhan rendah. Hal ini berdasarkan data hasil nilai pret-test yang dilakukan pada kelas eksperimen dan kelas kontrol. Pengusaan konsep siswa setelah menggunakan model siklus belajar tipe empiris induktif mengalami peningkatan. Terdapat kenaikan nilai rata-rata post-test pada siswa kelas eksperimen. Perbedaan penguasaan konsep siswa pada kelas yang menggunakan pembelajaran dengan siklus belajar empiris induktif dengan kelas kontrol berbeda signifikan. Hal ini berarti penguasaan konsep siswa kelas eksperimen lebih tinggi dibandingkan kelas kontrol yang menggunakan praktikum biasa. Tangapan siswa tentang penggunaan model siklus belajar tipe empiris induktif mendapat respon positif. Hampir seluruhnya siswa menyukai pembelajaran dengan menggunakan model siklus belajar tipe empiris induktif.

\section{Ucapan Terimakasih}

Terimakasih peneliti ucapkan kepada semua pihak yang telah ikut berpartisipasi dan membantu, memberikan saran, serta mendukung dalam pelaksanaan penelitian serta penulisan karya ilmiah yang telah dilakukan oleh peneliti.

\section{Referensi}

Aprilia, L., Lestariningsih, N., \& Ayatusa'adah. (2020). Pengembangan Penuntun Praktikum Berbasis Inkuiri Terbimbing Materi Interaksi Makhluk Hidup pada Siswa MTs Darul Amin Palangka Raya Lidia. Journal of Biology Learning, 2(2), 112-120.

Arlis, S., Amerta, S., Indrawati, T., Zuryanty, Z., Chandra, C., Hendri, S., ... Fauziah, M. (2020). Literasi Sains Untuk Membangun Sikap Ilmiah Siswa Sekolah Dasar. Jurnal Cakrawala Pendas, 6(1), 1-14. https://doi.org/10.31949/jcp.v6i1.1565

Asiyah, Walid, A., \& Topano, A. (2020). Perbandingan Hasil Belajar Model Pembelajaran Inquiry dengan Model Pembelajaran Kooperatif Learning Tipe Number Head Together (NHT) dalam Mata Pelajaran (IPA) Kelas V di Sekolah Dasar Negeri 66 Kota Bengkulu. IAIN Bengkulu. Journal of Biologi Learning, 2(2), 78-85.

Borup, J., Chambers, C., \& Srimson, R. (2019). Online teacher and on-site facilitator perceptions of parental engagement at a supplemental virtual high school. International Review of Research in Open and Distance Learning, 20(2), 79-95. https://doi.org/10.19173/irrodl.v20i2.4237

Bryan, Volchenkova, K. . (2016). Blended Learning: Definition, Models, Implications for Higher Education. Education Sciences, 8(2), 24-30. https://doi.org/10.14529/ped160204

Budiharti, R., Ekawati, E. Y., Wahyuningsih, D., \& H, F. F. (2015). Penggunaan Blended Learning dengan Media Moodle untuk Meningkatkan Kemampuan Kognitif Siswa SMP. Jurnal Cakrawala Pendidikan, 1(1), 140-148. https://doi.org/10.21831/cp.v1i1.4184

Ceylan, S., \& Ozdilek, Z. (2015). Improving a Sample Lesson Plan for Secondary Science Courses within the STEM Education. Procedia - Social and Behavioral Sciences, 177(July 2014), 223-228. https://doi.org/10.1016/j.sbspro.2015.02.395

Chaeruman, U. A., \& Maudiarti, S. (2018). Quadrant of Blended Learning: a Proposed Conceptual Model for Designing Effective Blended Learning. Jurnal Pembelajaran Inovatif, 1(1), 1-5. https://doi.org/10.21009/jpi.011.01

Creswell, J. W. (2014). Four Edition Research Design: Qualitative, Quantitative, and Mixed Methods Approaches. University of Nebraska Lincoln.

Daugherty, M. K. (2013). The Prospect of an "A" in STEM Education. Journal of STEM Education: Innovations and Research, 14(2), 10-15.

Dhawan, S. (2020). Online Learning: A Panacea in the Time of COVID-19 Crisis. Journal of Educational Technology Systems, 49(1), 5-22. https://doi.org/10.1177/0047239520934018

Dziuban, C., Graham, C. R., Moskal, P. D., Norberg, A., \& Sicilia, N. (2018). Blended learning: the new normal and emerging technologies. International Journal of Educational Technology in Higher Education, 15(1), 1-16. 
https://doi.org/10.1186/s41239-017-0087-5

Fauzi, I., \& Sastra Khusuma, I. H. (2020). Teachers' Elementary School in Online Learning of COVID-19 Pandemic Conditions. Jurnal Iqra' : Kajian Ilmu Pendidikan, 5(1), 58-70. https://doi.org/10.25217/ji.v5i1.914

Fitriyana, N., Wiyarsi, A., Ikhsan, J., \& Sugiyarto, K. H. (2020). Android-based-game and blended learning in chemistry: Effect on students' self-efficacy and achievement. Cakrawala Pendidikan, 39(3), 507-521. https://doi.org/10.21831/cp.v39i3.28335

Han, S., Rosli, R., Capraro, M. M., \& Capraro, R. M. (2016). The effect of Science, technology, engineering and mathematics (STEM) project based learning (PBL) on students' Achievement in four mathematics topics. Journal of Turkish Science Education, 13(Specialissue), 3-30. https://doi.org/10.12973/tused.10168a

Jarwati, \& Priskawati, D. (2020). Blended Learning: Solusi Pembelajaran New Normal Untuk Pendidikan Agama Kristendi Era Revolusi Industri 4.o. Jurnal Pendidikan DIDAXEI, 1(2), 103-113.

Lestari, H., Banila, L., \& Siskandar, R. (2019). Kemandirian Belajar Melalui Pembelajaran Berbasis STEM Improving Student' S Science Literacy Competencies Based On Learning Independence With Stem Learning, 14(2), 18-23.

Lestari, H., \& Rahmawati, I. (2020). Integrated STEM through Project Based Learning and Guided Inquiry on Scientific Literacy Abilities in Terms of Self-Efficacy Levels. $A l$ Ibtida, $7(1), 19-32$.

Lestari, H., Setiawan, W., \& Siskandar, R. (2020). Science Literacy Ability of Elementary Students Through Nature of Science-based Learning with the Utilization of the Ministry of Education and Culture â€ $€^{\mathrm{TM}} \mathrm{s}$ " Learning House ." Journal of Research in Science Education, 6(2), 215-220. https://doi.org/10.29303/jppipa.v6i2.410

Lestari, H., \& Siskandar, R. (2020). Literasi Sains Siswa Melalui Penerapan Model Pembelajaran Blended Learning Dengan Blog. NATURALISTIC: Jurnal Kajian Penelitian Pendidikan, 4(2), 597-604.

Lestari, H., \& Widodo, A. (2021). Peranan Model Pembelajaran Nature of Sains Untuk Meningkatkan Pemahaman Sains Siswa Sekolah Dasar. Jurnal Cakrawala Pendas, $7(1), 1-9$.

Richardson, J. W., Lingat, J. E. M., Hollis, E., College, R., \& Pritchard, M. (2020). Shifting teaching and learning in online learning spaces: An investigation of a faculty online teaching and learning initiative. Online Learning Journal, 24(1), 67-91. https://doi.org/10.24059/olj.v24i1.1629

Setiawan, B., \& Iasha, V. (2020). Corona Virus Disease 2019: The Perspective Opinion From Pre-Service Elementary Education Teacher. Education, Sustainability \& Society, 3(2), 33-36. https://doi.org/10.26480/ess.02.2020.33.36

Soler, R., Soler, J. R., \& Araya, I. (2017). Subjects in the Blended Learning Model Design. Theoretical-Methodological elements. Procedia - Social and Behavioral Sciences, 237(June 2016), 771-777. https://doi.org/10.1016/j.sbspro.2017.02.120

Sopandi, W. (2019). Sosialisasi dan Workshop Implementasi Model Pembelajaran RADEC Bagi Guru-Guru Pendidikan Dasar dan Menengah [Dissemination and Implementation Workshop of RADEC Learning Models for Primary and Secondary Education Teachers]. PEDAGOGIA: Jurnal Pendidikan, 8(1), 19. https://doi.org/10.21070/pedagogia.v8i1.1853

Yuliati, Y. (2017). Literasi Sains Dalam Pembelajaran Ipa. Jurnal Cakrawala Pendas, 3(2), 21-28. https://doi.org/10.31949/jcp.v3i2.592 